\title{
Kotiinpaluun kronotoopit suomalaisessa sisällissotakirjallisuudessa
}

\section{Sisällissodan jälkeiset kotiinpaluut}

Eeva Joenpellon Vetää kaikista ovista -romaanin ${ }^{1}$ alussa on teoksen koskettavin kohtaus. On kevät 1919. Kapinasta on kulunut vuosi. Punaleski Tilta Gröönroos tulee tapaamaan serkkuaan, kauppiaanrouva Salme Hännistä. Tilta on menettämässä kaiken. Hänen miehensä suutari Gröönroos on kuollut vankileirillä punatautiin ja hänen verstaansa on myyty velkojen katteeksi. Tytär Hilja makaa kotona espanjantaudissa. Ei ole ruokaa eikä rahaa, ja poika Vieno viruu vankileirillä. Tilta kiertää talosta taloon pyytäen, että joku isännistä kirjoittaisi paperin, jossa tarjoaisi Vienolle töitä. Se on ainoa tapa saada hänet pois vankileiriltä, "[p] ois kualemast. Selväst kuolemast." Tiltan ainoa toivo on saada Vieno kotiin hengissä, "vaik kui vähis henkis. Nii kyl mää sen hoiraisi ihmiseks taas." (Joenpelto 1972, 16-17.)

Salme antaa serkulleen syötävää kotiin viemisiksi ja Tilta sopottaa asiansa kotiin palaavalle kauppiaalle. Jotain tapahtuukin. Kun Salme myöhemmin lähettää tyttärensä Inkerin ja Anjan viemään hänelle ruokaa, heitä kohtaa erikoinen näky:

[Gröönrooska] istui ulkohuonerakennuksen rappusella jonkun miehen vieressä. Mies oli paljain jaloin ja piteli päätään käsissään. Heidän seistessään siinä hänen kätensä putosivat ja hän paljasti hitaasti kuivuneet kasvot, suuret syvistä kuopista katsovat hohdottomat silmät. Gröönrooska pani kätensä miehen olkapäälle, irrotti, nousi sitten ja lähti tyttöjä kohden. (Joenpelto 1972, 32.)

1 Vetää kaikista ovista (1972) aloittaa Lohja-sarjaksi tai Uusimaa-sarjaksi nimitetyn Eeva Joenpellon 1970-luvulla kirjoittaman tetralogian, jonka muut osat ovat: Kuin kekäle kädessä (1974), Sataa suolaista vettä (1978) ja Eteisiin ja kynnyksille (1980). Lohja-sarjasta ks. esim. Mahlamäki 2005. 
Nuo Vienon kuivuneet kasvot ovat tuttuja monista muista sisällissodan ${ }^{2}$ vankileirien kuvauksista. Ne ovat tuttuja myös muiden sotien vanki- ja keskitysleirikuvauksista, erityisesti toisen maailmansodan aikaan mutta myös 1990-luvun Balkanin sodista. Nuo syvistä kuopista katsovat nälkiintyneiden lapsien silmät ovat tuttuja nälänhädistä kertovissa uutisissa tai itsensä näännyttäneiden, syömishäiriöstä kärsivien tyttöjen kasvoissa. Ne herättävät katsojassa pelkoa ja vihaa sekä halun auttaa.

Myös Joenpellon romaanin Salme tyttärineen haluaa auttaa. Siksi Anja ja Inkeri tulevat tapaamaan Tiltaa. Hän sanoo heidän tulleen liian myöhään. Vielä teini-ikäinen tytär Hilja on kuollut edellisenä yönä nälän heikentämänä. Espanjantauti huipentui 1910luvun lopulla Suomessa ja Euroopassa tappaen ihmisiä, jotka olivat sodalta tai nälältä säästyneet. ${ }^{3}$ Romaanin Hilja oli yksi heistä. Mutta Gröönrooskan elämässä oli vielä toivoa. Hänen poikansa Vieno oli palannut kotiin.

Kesästä 1918 aina kevääseen 1919 elettiin punaisten perheissä kotiinpaluiden aikaa - niissä perheissä, joissa oli jotain odotettavaa. Sisällissotaa käsittelevässä muistitietoaineistossa isän kotiinpaluu onkin yksi tärkeistä teemoista. ${ }^{4}$ Tiltan ja Vienon kohtaamisen innoittamana ryhdyin etsimään sanataiteen kuvauksia vuoden 1918 tapahtumien jälkimainingeista. Erityisesti etsin romaaneista kohtauksia, joissa puoliso, vanhempi tai aikuinen lapsi palaa kotiin sodasta pitkän poissaolon jälkeen. Useimmiten he palasivat vankileiriltä, mikä tarkoittaa, että he olivat lähteneet sotaan punaisten puolella. Valkoisten kotiinpaluita en tässä yhteydessä tarkastele, vaikka niidenkin kuvauksia suomalaisesta kaunokirjallisuudesta löytyy. ${ }^{5}$ Olen valinnut käsittelyyni eri vuosikymmeninä kirjoitettuja teoksia tai novelleja, jotta kirjoittamisajankohdan mahdollinen vaikutus kuvauksiin tulisi selvemmin esiin.

Artikkelissani kysyn: Miten suomalaisessa kaunokirjallisuudessa on kuvattu vuoden 1918 sodasta ja sen jälkeiseltä vankileiriltä kotiin palaavia miehiä ja naisia? Mistä näkökulmasta ja minkälaisiksi kotiin palaavan ja kotona odottavan kohtaamiset on kuvattu? Mitkä teemat korostuvat tai toistuvat kuvauksissa? Analyyttisenä apuvälineenä sovellan venäläisen kirjallisuudentutkijan Mihail Bahtinin (1979) kronotoopin käsitettä. Sen ohjaamana kysyn: minkälaisia aikatiloja kohtaamisten sanataiteellisissa kuvauksissa rakentuu?

2 Käsittelemissäni romaaneissa puhutaan useimmiten kapinasta. Termiä käyttivät myös punaisten puolelle identifioituneet. Sodasta käytetyt nimitykset asemoivat pitkään puhujan suhteen sodan osapuoliin. Omassa tekstissäni käytän nykytutkimuksessa suositeltavaa ja yleistä sekä neutraaliksi koettua sisällissota-termiä. Sodan nimityksistä ks. Heimo 2010, 31-32. Perusteellisesti aihetta on käsitelty Historiallisen aikakauskirjan 2/1993 teemanumerossa "Yksi vai monta totuutta?"

3 Espanjantaudista ks. esim. Eila Linnanmäki 2005: Espanjantauti Suomessa - influenssapandemia 1918-1920. Helsinki: SKS.

4 Esim. Peltonen 1996; Fingerroos 2004; Heimo 2010; Suomalaisen Kirjallisuuden Seuran arkiston, Kansan arkiston ja Sirkkala 1918-2018 -hankkeen vuoden 1918 muistitietoa käsittelevät kokoelmat ja aineistot.

5 Esimerkiksi Linnan Pohjantähti-trilogia, jossa kotiin palaa jääkäri Ilmari Salpakari tai Kjell Westön Missä kuljimme kerran romaani, jossa sotaa ja sen seurauksia tarkastellaan sekä punaisesta että valkoisesta näkökulmasta. 


\section{Sisällissotakirjallisuuden kronotoopit}

\subsection{Kronotoopin käsite}

Kirjallisuudessa kuvatut tapahtumat ja henkilöhahmot ovat aina jossain ympäristössä ja jossakin ajassa, ja nämä ajan ja tilan motiivit tematisoituvat useilla tavoilla. Ajan ja paikan kohtaamista voi tarkastella kronotoopin eli aikatilan käsitteellä. Käsitteen toi kirjallisuudentutkimukseen venäläisfilosofi Mihail Bahtin vuonna 1938 valmistuneessa laajassa esseessään "Ajanilmaisujen ja kronotoopin muodot romaanissa". Bahtinin mukaan kronotoopissa "paikalliset ja ajalliset tunnusmerkit ovat punoutuneet toisiinsa mielekkääksi ja konkreettiseksi kokonaisuudeksi”. (Bahtin 1979, 243-244; Mahlamäki 2005, 33-35.)

Bahtinin mukaan käsite kuvaa siis romaanien maailmassa tapahtuvaa ajan ja tilan yhteen kietoutumista, jossa "[a]ika tihenee, tiivistyy ja tulee taiteellisesti havaittavaksi; tila puolestaan voimaperäistyy, kietoutuu ajan, juonen ja historian kulkuun", siinä "[a]jan tunnusmerkit avautuvat tilassa ja tila ymmärretään ja mitataan ajallisesti". (Bahtin 1979, 243-244; 1981, 84; 1988; Mahlamäki 2005, 37.) Sanataiteessa kuvattava tapahtumien tila tai paikka on yleensä selvemmin havaittavissa, kuten vaikkapa edellisen luvun lainauksessa, jossa ollaan Gröönrooskan kodin ulkohuonerakennuksen rappusella. Kohtauksen aika ja henkilöhahmojen kokemus ajasta sen sijaan ei tule suoraan esiin, mutta kirjallisuuden ominaisuuksiin kuuluu, että siinä myös aika "tulee taiteellisesti havaittavaksi" eli lukijalle näkyväksi.

Olen uskontotieteen väitöstutkimuksessani (2005) tarkastellut Joenpellon Lohja-sarjaa kronotoopin näkökulmasta ja siinä totean, että "aika, sen kokeminen ja sen suhteellisuus kuten myös tilan merkitykset ja kokeminen ovat näkymättömiä, abstrakteja asioita, jotka sanataiteessa voidaan tehdä näkyviksi” (Mahlamäki 2005, 37). Niin myös Tiltan, Vienon ja Hännisen sisarusten kohtaamisessa on läsnä monenlaisia ajan kokemuksia ja merkityksiä: Tiltan puoliso ja tytär ovat kuolleet, he kuuluvat menneisyyteen. Vienon kotiintulo saa Tiltan katsomaan tulevaisuuteen toivoen. Vieno itse on nuori mies, mutta kärsimyksiensä vuoksi ikävuosiaan vanhempi niin mieleltään kuin ulkoiselta olemukseltaan.

Bahtin ja lukuisat hänen jälkeensä tulleet tutkijat ovat käyttäneet kronotoopin käsitettä monin eri tavoin. Käsite toimii tutkimuksissa kolmella tasolla: Sen voi ensiksikin nähdä keinona, jolla teksti representoi eli esittää historiaa. Toiseksi sitä voi tarkastella romaanissa esiintyvien ajan ja paikan kuvien suhteena sekä kolmanneksi tapana pohtia tekstin itsensä muodollisia ominaisuuksia, kuten juonta, kuvausta ja suhdetta toisiin teksteihin. (Vice 1997, 201-202; Mahlamäki 2005, 39.) Yksi keskeisimmistä käyttötavoista on soveltaa Bahtinin (1979) esittelemiä romaanin sisäisiä kronotooppisia yksiköitä, joita ovat esimerkiksi tapaamisen, tien, idyllin, kynnyksen ja salongin kronotoopit, joita hän esseessään kuvaa. Useat tutkijat ovat sen jälkeen tulkinneet eri teksteistä löytämiään erilaisia kronotooppisia yksiköitä. Kyse on siis kronotooppi-käsitteen heuristisesta soveltamisesta. Väitöstutkimuksessani Lohja-sarjan tulkintakehyksenä oli kehämäisesti rakentuva sukupuolittunut kansalaisuus, ja tarkastelemani kronotooppiset yksiköt olivat keittiö, koti, kylä ja kansakunta. Tässä artikkelissa kehystän tulkintani käyttäen näkökulmanani 
kronotoopin käsitettä uskontotieteen näkökulmasta tarkastelleen Thomas A. Tweedin teoriaa. Tweed $(2006,97)$ nostaa tunnetussa teoksessaan Crossing and Dwelling: A Theory of Religion esiin neljä ihmiselämälle, yhteisöille ja uskonnolle merkityksellisintä ajan ja tilan kohtaamispistettä, kronotooppia: keho, koti, kotimaa ja kosmos. Luin kaunokirjallisuuden kotiinpaluiden kuvauksia keskittyen erityisesti näihin aikatiloihin. Tarkastelenkin seuraavassa aineistoani kehon, kodin ja kotimaan kronotooppien näkökulmasta - kosmoksen kronotooppi ei tässä aineistossa noussut esiin. Aloitan kuitenkin Bahtinin itsensä esittelemästä kohtaamisen kronotoopista.

\subsection{Kotiinpaluiden kronotooppiset yksiköt: kohtaaminen, keho, koti ja kotimaa}

Luonnollisin tapa tarkastella kotiinpaluita on Bahtinin kohtaamisen tai tapaamisen kronotooppi. Tosin Bahtinille kohtaamiset eivät tapahdu kotona, sillä hän yhdistää toisiinsa kohtaamisen ja tien kronotoopit. Matkojen varsilla tapahtuukin monenlaisia kohtaamisia, ja ilman niitä harva romaani tulee toimeen. Bahtinin mukaan " $[\mathrm{t}]$ ien kronotoopissa paikallisten ja ajallisten määritysten yhteisyys tulee ilmi erittäin selvästi ja näkyvästi”. (Bahtin 1979, 257, 408; 1981, 243-245.) Myös Vetää kaikista ovista -romaanin Tiltan ja Vienon kohtaaminen tapahtuu tiellä, kotiin johtavalla metsäpolulla, jonka sivuun Vieno on väsyneenä tuupertunut.

Tie on tapahtumien kehkeytymispiste ja toteutumispaikka. Tiellä voivat sattumalta tavata ne, joita tavallisesti erottaa toisistaan sosiaalinen hierarkia tai avaruudellinen etäisyys, tiellä saattaa muodostua monenlaisia kontrasteja, ja erilaiset kohtalot saattavat törmätä yhteen tai punoutua toisiinsa. Ihmiskohtaloiden ja elämäntaipaleiden paikalliset ja ajalliset jonot nivoutuvat omalaatuisesti yhteen, ja tiellä häviävät sosiaaliset välimatkat tekevät ne monimutkaisiksi ja konkreettisiksi. (Bahtin 1979, 408.) Kotiinpaluut tapahtuvat nimensä mukaisesti useimmiten kotona tai kotiin johtavalla tiellä, mikä tekee niistä aivan omanlaisiaan, useimmiten perheenjäsenten keskinäisiä kohtaamisia, joissa on läsnä myös kohtaajien yhteinen menneisyys ja edessä odottava tulevaisuus.

Keho, ihmisruumis, on aina keskeinen ja ensisijainen kokemisen tila. Kun puhutaan ruumillisista kokemuksista, on niiden aika aina tässä ja nyt. Kehon kronotooppi kantaa kuitenkin mukanaan menneisyyttään, muistoja ja jälkiä aikaisemmista kokemuksista. Esimerkkinä vaikkapa edellä kuvatun Vienon nälkiintyneet kasvot ja tyhjyyteen katsovat silmät. Ruumis on aina myös sukupuolittunut, ja sillä on erityiset ruumiilliset tarpeet ravinto, puhtaus, huolenpito -, jotka määrittävät paitsi kokemuksia myös kohtaamisia ja suhteita toisiin ihmisiin, toisiin ihmiskehoihin. (Tweed 2006, 99-100.) ${ }^{6}$

Kehon kronotooppia laajempi on kodin kronotooppi, joka ei rajoitu pelkästään fyysiseen kotitaloon. Se voi laajeta koko lähiympäristöön ja kotiseutuun. Se ei kiinnity välttämättä silti tiettyyn asuinpaikkaan, sillä koti voidaan kokea myös mielentilana ja tunteena. Kuten keho on suhteessa toisiin, erityisesti koti yhdistyy läheisiin ihmisiin, perheeseen ja perheenjäsenten välisiin suhteisiin. Koti aikatilana kiinnittyy arjen, vuodenkierron ja

6 Ihmiskehosta keskeisenä orientoitumisen tilana ks. myös Knott 2005. 
elämänvaiheiden syklisyyteen ja toistuviin tekemisiin ja tapahtumiin. (Mahlamäki 2005, 118; Tuan 2001, 6; Douglas 2001.)

Anni Vilkko $(1998,28)$ käyttää käsiteparia kodin tuntu kuvaamaan sitä, miten jokin paikka koetaan kodiksi, miten johonkin paikkaan syntyy kuulumisen side ja omaksi kokeminen. Tweed $(2006,105)$ määrittelee kodin yksityiseksi, rajalliseksi tilaksi, joka vastaa ruumiillisiin tarpeisiin - suoja, uni, seksuaalinen kanssakäyminen, huolenpito ja ruoka ja jossa usein, mutta ei aina, asuu muita perheenjäseniä. Koti on sosiaalinen tila, julkisen ja yksityisen kohtauspaikka. Sen tilat ja siellä toteutettavat roolit sekä tehtävät asiat ovat usein sukupuolittuneita. (Mahlamäki 2005, 116; Saarikangas 1998, 284.)

Vaikka ensinäkemältä tuntuu siltä, että kotimaata, kansakuntaa rajaavat valtion rajat, ei asia ole niin yksinkertainen. Kansakunta on, Benedict Andersonin termein, kuviteltu tila, jota asuttaa kuviteltu yhteisö. Se viittaa sosiaaliseen tilaan, jota asuttaa yhteisö, jota yhdistää esimerkiksi yhteinen kieli, kulttuuri ja uskonto. Yhteisö koostuu kuitenkin pienemmistä ryhmistä, jotka kuvittelevat kotimaansa eri tavoin ja voivat myös kuvitella toisensa sen ulkopuolelle. Kotimaan jakava yhteisö ei siis ole yhtenäinen, vaan yhteisön sisällä kulkee monenlaisia kuviteltuja tai konkreettisia sen eri osia erottavia rajoja ja aitoja. (Anderson 1991; Tweed 2006, 110-111.)

Kotimaa on omaa kehoa ja kotia abstraktimpi tila, joka tulee näkyviin erilaisina representaatioina ja merkityksinä, kertomuksia kehystävinä diskursseina. Kotimaa on jäsenilleen abstrakti idea, merkitysjärjestelmä ja representaatio, ei niinkään ihmisten tai romaanien henkilöhahmojen arjessa tai elämässä konkretisoituva asia. (Mahlamäki 2005, 160-161.) Jos kotimaan kronotooppi on tilan näkökulmasta ruumista ja kotia abstraktimpi, on siinä niitä vahvemmin läsnä moniaikaisuus, kansakunnan menneisyys, nykyisyys ja tulevaisuus. Kansakunnan tai kotimaan kronotooppi toimii usein kyseenalaistamattomana taustapaperina, jonka päälle omaa kansalaisuutta rakennetaan (Mahlamäki 2005, 225).

\section{Kotiinpaluun teemat sisällissotakirjallisuudessa}

\subsection{Aiempi tutkimus ja aineisto}

Vuoden 1918 tapahtumia käsittelevää kaunokirjallisuutta on esitelty, luetteloitu ja tutkittu paljon. ${ }^{7}$ Tuorein sisällissotaa ja kaunokirjallisuutta käsittelevä teos on artikkelikokoelma Toistemme viholliset (2018), joka julkaistiin sisällissodan syttymisen 100-vuotispäivänä. Kirjallisuus käsitetään kokoelmassa laajasti: se sisältää myös sarjakuvat, kuvataiteen,

7 Ks. esim. Heimo 2010, 24-28, 126. Kaunokirjallisuutta ja sisällissotaa on käsitelty mm. seuraavissa lähteissä: Maria-Liisa Kunnas 1976: Kansalaissodan kirjalliset rintamat eli kirjallista keskustelua vuonna 1918. SKS, Helsinki; Juhani Niemi 1988: Viime sotien kirjat. SKS, Helsinki; Kirsi Nurmio 1988: Kansalaissota kaunokirjallisuudessa. Suomi8o-sivusto. Tampereen yliopisto. http://www15.uta. fi/yky/arkisto/suomi8o/art14.htm; Lasse Koskela (1999): Kansa taisteli - valkoiset kertovat. Teoksessa Lea Rojola (toim.): Suomen kirjallisuushistoria 2. Järkiuskosta vaistojen kapinaan. SKS, Helsinki; Yrjö Varpio (2009): Vuosi 1918 kaunokirjallisuudessa. Teoksessa Pertti Haapala ja Tuomas Hoppu (toim.): Sisällissodan pikkujättiläinen. WSOY, Helsinki. 
teatterin ja musikaalit. Tekstikokoelmassa käsitellään muun muassa Lauri Viidan Moree$n i$, F. E. Sillanpään Hurskas kurjuus, Toivo Pekkasen Tehtaan varjossa ja Elvi Sinervon $P a-$ lavankylän seppä romaaneja sekä Runar Schildtin novellikokoelman niminovellia Hemkomsten/Kotiinpaluu. Suomenruotsalaisella kirjallisuudella ja sisällissotatulkinnoilla onkin vahva osa kokonaisuudessa, sillä Schildtin lisäksi käsittelyyn tulevat Elmer Diktoniuksen Janne Kubik / Janne Kuutio sekä Sigrid Backmanin sisällissotaromaanit. Artikkelikokoelmassa yksinkertaistetut käsitykset sisällissodan kahtia jakamasta kansakunnasta osoitetaan vanhentuneiksi. Taide ja kirjallisuus näyttävät voimansa vaikeiden ja mahdottomien asioiden käsittelyssä ja työstämisessä.

Teoksen toimittajat Kukku Melkas ja Olli Löytty (2018b) huomioivat, miten sisällissotaan on kirjallisuudessa palattu eri aikoina eri tavoin. Erityisen runsaasti aihetta on ryhdytty käsittelemään 2000-luvulle tultaessa, jolloin etäisyys sotaan on kasvanut tarpeeksi pitkäksi. Sisällissotaa käsittelevä kaunokirjallisuus ja sisällissotaan kohdistuva historiantutkimus kulkevat käsi kädessä. Esimerkiksi Anneli Kannon Veriruusut (2008) nojautuu vahvasti alkuperäisiin dokumentteihin sekä Anu Hakalan tutkimukseen Housukaartilaiset (2006). Naisten osuus ja naisten näkökulma sisällissotaan on myös 200o-luvun sisällissotakirjallisuuden erityispiirre. ${ }^{8}$

Historiallisia tapahtumiakin käsitellessään kirjallisuus peilaa aina ilmestymisaikaansa. Melkas ja Löytty (2018b) nostavat yhdeksi tällaiseksi teemaksi vihapuheen ja sen konkreettiset seuraukset. Viholliskuvan synnyttämiseen tarvitaan systemaattista vihapuhetta, jota löytyy niin vuoden 1918 tapahtumia edeltäviltä ajoilta kuin nyky-Suomesta. Melkas ja Löytty (mts., 31) kirjoittavat:

Ajallinen etäisyys luo historialliselle romaanille mahdollisuuden olla toisaalta syyttelemättä ketään erityistä osapuolta, toisaalta taas olla oikeuttamatta joitain tiettyjä tekoja. Ruohonjuuritason näkökulmastaan huolimatta - tai juuri siksi sisällissotaa käsittelevät nykyromaanit onnistuvat kuvaamaan sodan vaikutuksia koko kansakunnan psyykeeseen. Ne ovat kertomuksia siitä, kuinka Suomi meni rikki.

Avaan seuraavassa kronotooppisen yksikön näkökulmasta kaunokirjallisuuden kuvauksia kotiinpaluusta. Jo aiemmin esittelemäni Eeva Joenpellon Vetää kaikista ovista -romaanin (1972) lisäksi tarkastelen Runar Schildtin novellia "Kotiinpaluu" (1919) sekä seuraavia romaaneja: Toivo Pekkasen Tehtaan varjossa (1930), Väinö Linnan Täällä Pohjantähden alla (1959-1962), Hella Wuolijoen Työmiehen tarina (1940/1970), Juhani Syrjän Juho 18 (1998) ja Heidi Köngäksen Sandra (2017). ${ }^{9}$ Tarkastelen kotiinpaluun

8 Tutkimusten naisnäkökulmasta ks. erityisesti seuraavat teokset: Tuomas Hoppu 2008: Tampereen naiskaarti: Myytit ja todellisuus. Ajatus, Helsinki; Tuomas Hoppu 2017: Sisällissodan naiskaartit: suomalaisnaiset aseissa 1918. Gummerus, Helsinki; Tiina Lintunen 2015: Punaisten naisten tiet. Valtiorikosoikeuteen vuonna 1918 joutuneiden Porin seudun naisten toiminta sota-aikana, tuomiot ja myöhemmät elämänvaiheet. Turun yliopisto, Turku.

9 Näiden lisäksi olen tutustunut laajempaan joukkoon vuotta 1918 käsittelevää romaanikirjallisuutta: 
kuvauksia neljän, teoksista lähiluvun avulla löytyneen ja kohtauksia yhdistäneen teeman lävitse: kuollut palaa kotiin, tappava ruoka, palaajana työtätekevä kansa sekä lapsi palaa kotiin.

\subsection{Kuollut palaa kotiin}

Runar Schildtin novelli "Hemkomsten" eli "Kotiinpaluu” oli aikalaiskuvaus. Vuonna 1919 ilmestyneenä se on yksi ensimmäisiä sisällissodan tapahtumia kuvaavia fiktiivisiä tekstejä. Ilmari Ahma suomensi novellikokoelman tuoreeltaan vuonna 1922. Sisällissodan 65-vuotismuiston kunniaksi vuonna 1983 Love-kirjat julkaisi suomennoksen uudelleen. Niin Schildt kuin samana vuonna 1919 Hurskas kurjuus -romaanin julkaissut F. E. Sillanpää pyrkivät ylittämään sisällissodan yksinkertaistetut vastakkainasettelut ja näkemään asetelman moniulotteisempana. Sillanpää analysoi romaanissaan tarkasti sotaan johtaneita sosiaalisia ja taloudellisia syitä. Vaikka Hurskas kurjuus kuvaakin yhden henkilön, Jussi Toivolan, elämäkertaa, kertoo se samalla tarinaa yhtä ihmistä suuremmasta joukosta. (Melkas-Löytty 2018b, 18.)

Sillanpää kuvaa kohdettaan läheltä ja tarkkaan. Samoin tekee Runar Schildt tarkastellessaan novellissaan "Kotiinpaluu” pientä, syrjäseudulla asuvaa perhettä, jonka vanhin poika on lähtenyt sotaan, kadonnut ja kuollut. Isä ja avioitumisensa jälkeen mökkiin asumaan jäänyt nuorempi poika kuuluvat suojeluskuntaan ja kannattavat muiden kyläläisten tavoin valkoisia. Sahalla työskennellyt Albin oli kylästä ainoana lähtenyt sotaan punaisten puolelle ja näin tuottanut perheelleen pettymyksen. Hänen kuolemansa oli paitsi surun myös häpeän leimaama, minkä vuoksi Albinin nimeä ei perheessä enää mainittu. Punaisten puolella kuolleiden julkinen sureminen oli mahdotonta (ks. esim. Peltonen 2006, 17).

Novellin päähenkilö on perheen äiti Mari, joka valvoo eräänä yönä selkäsäryssään ja kuulee jonkun tulevan pihaan ja rapistelevan portailla. Hän menee ovelle ja sitä avaamatta kysyy kolme eri kertaa, kuka vieras on. Vieras kertoo olevansa Marin esikoispoika Albin. Mari puolestaan uskoo oven toisella puolella seisovan haamun. Hänen poikansa on jäänyt vaille kristillisiä hautajaisia ja vaeltaa siksi levottomana maan päällä ja tulee tapaamaan äitiään yön pimeydessä. Kuvaus rakentaa jännitystä, kuin kummitustarinaa ${ }^{10}$ äidin näkökulmasta:

- onko siellä joku? Sai hän vihdoin kolmannen kerran sanotuksi. - Päästäkää minut sisään, vastasi sama ääni, nyt kiihkeämmin, pyytävämmin kuin äsken,

Ilmari Kianto Ryysyrannan Jooseppi (1924); Ilpo Kaukovalta: Lippujen hulmutessa (1938); Elvi Sinervo: Palavankylän seppä (1965); Erkki Lepokorpi: Käy ruusutkin kukkimaan (1977); Anneli Kanto: Veriruusut (2008); Elisabet Aho: Sisar (2011); Kjell Westö: Missä kuljimme kerran (2006) ja Kangastus 38 (2013).

10 1960-luvulla arkistoihin lähetetystä vuotta 1918 käsittelevästä muistitietoaineistosta löytyy lukuisia kummitteluun liittyviä uskomustarinoita. Niissä vainajat pyrkivät siunattuun maahan, kummittelevat ja ahdistavat surmaajiaan. Ulla-Maija Peltonen toteaa, että suurin osa kertojista on naisia, jotka näkevät tehtäväkseen pitää yllä miesvainajiensa muistoa. (Heimo 2010, 244; Peltonen 1996, 237-239). 
mutta yhtä salaperäisen hillittynä ja arkana. - Antakaa minun puhua kanssanne, minun täytyy poistua jälleen, kun aamu valkenee.

Niin, se oli todella vainajan ääni. Äiti ei erehdy esikoisensa äänestä. Mari seisoi siinä ja tunsi keinuvansa raskaan huumauksen vallassa. Nyt hän ymmärsi. Ja samassa tuntui hänestä luonnolliselta, melkein itsestään selvältä, että Albin tuli keskiyön aikaan ja pyysi päästä sisään lapsuudenkotiinsa. Hän oli ajatellut tätä jo monta kertaa, ihmetellyt, odottanut melkein, varsinkin ensi aikoina tiedon saavuttua pojan kuolemasta. Albin, joka oli ollut mukana niin kauheissa teoissa, ehkä itsekin tehnyt törkeitä rikoksia, kuinka hän voisi saada lepoa joukkohaudan siunaamattomassa mullassa. (Schildt 1983 [1919], 136.)

Kohtauksessa seistään kahden puolen ovea, mutta samalla kahden puolen todellisuutta, tämän- ja tuonpuoleisen kuvitellulla rajalla, kahdessa eri aikatilassa. Äiti lausuu hautaanasettamissanoja vapauttaakseen poikansa haamun jatkamaan matkaansa tuonpuoleiseen. Poika kuitenkin vakuuttaa olevansa elossa ja kävelleensä Venäjän Karjalasta kaksi kuukautta päästäkseen kotiseudulleen. Äiti tekee oudon ja kauaskantoisen päätöksen eikä päästä poikaansa sisään. Hän ei halua asettaa tätä perheen miesten vihalle: ”...lienee parasta, ettet lainkaan astu sisään ja herätä heitä, mutta minä tulen ulos ja kuuntelen mitä sinulla on kerrottavana. Huomenna voimme katsoa, mitä ehkä voi saada aikaan." (Schildt 1983, 139.)

Pimeä, öinen piha on muusta perheestä ja muusta maailmasta erillinen aikatila, jossa äiti ja poika tapaavat. Albin raapaisee tulitikun, että äiti näkee hänen kasvonsa:

Niin, kyllä siinä oli Albin, vaikkakin hän tuntui paljon muuttuneen. Puolipitkä parta, jota hänellä ei ollut ennen ollut, ulottui korvasta toiseen. Mari kerkesi ajatella, että pojan täytyi nyt tietysti tehdä kaikkensa, etteivät kunnialliset ihmiset häntä tuntisi. Häntä värisytti. Pieni liekki heikkeni yhä, hän saattoi nähdä vain että nenä pisti omituisen terävänä esiin Albinin laihtuneista ja jollakin tavoin jäykistyneistä kasvoista. Silmät olivat vajonneet syvemmälle kuin ennen - tai ehkä se johtui vain lepattavasta valosta. Samassa tulitikku käyristyi ja katkesi. (Schildt 1983, 140.)

Kotiin palaava poika on fyysisesti muuttunut, kasvattanut parran, jotta häntä ei tunnistettaisi, ja kärsimys näkyy hänen kasvoistaan. Erityisesti äidin huomion kiinnittävät Albinin jäykistynyt ilme ja muuttunut katse. Haamusta Albin muuttuu ruumiilliseksi, eläväksi ihmiseksi, vaikkakin vain lyhyeksi ajaksi. Nopeasti palavan tulitikun liekki yhdistää heidät hetkeksi samaan tilaan ja todellisuuteen.

Jatkossa Albin joutuu edelleen elämään piilossa. Marin päätöksestä muut perheenjäsenet eivät saa tietää hänen paluustaan, sillä häntä uhkaa kuolemantuomio tai pitkä vankeus sodanaikaisista teoistaan. Melkas ja Löytty $(2018$ b, 20) huomaavat novellin tiheän ja jännittyneen tunnelman rakentuvan yhtäältä äidin kiihkeiden aistimusten lävitse ja toisaalta siitä tosiasiasta, että sisällissodan monimutkaiset ja osin summittaisetkin jakolinjat 
kulkevat kuvattavan perheen sisällä. Ruotsinkielisessä työläisperheessä sekä veli että isä kuuluvat suojeluskuntaan, mutta Albin oli lähtenyt punaisten kaartiin miltei päähänpistosta, taitavan suostuttelun ansiosta.

Mari tapaa poikaansa säännöllisesti ja iloitsee siitä, että saa pitää hänet itsellään. Hän joutuu myös valehtelemaan muulle perheelleen ja varastamaan ruokaa sekä muita tarvikkeita, joita piilotteleva Albin tarvitsee. Äiti vaikuttaa maaniselta, toimii itselleen poikkeuksellisin tavoin ja herättää epäluuloja kotonaan. Hänelle merkitykselliseksi todellisuudeksi muodostuvat ne lyhyet hetket, jolloin hän pääsee tapaamaan poikaansa tämän piilopaikkaan. Koti ja kylä ovat vain paikkoja, joista hankkia tarvikkeita ja elintarpeita. Aikaa myöten sekä Mari että Albin käyvät varomattomiksi. Kyläläiset lähtevät etsimään varastelevaa karkulaista. Marille annetaan mahdollisuus kertoa totuus, mutta hän ei suostu paljastamaan salaisuuttaan eikä liioin anna Albinin antautua. Novellin loppu jää avoimeksi: kuoleeko siinä Albin vai Mari vai molemmat? Novelli osoittaa, miten monimutkaisista suhteista ja tilanteista sisällissodassa lopultakin oli kyse. Se tarkastelee myös syyllisyyttä ja sitä, miten helposti tavallinen ihminen - sekä sisällissotaan mielijohteesta ajautunut Albin että häntä auttava äiti - voi ajautua ympäröivän yhteisön näkökulmasta rikollisiin tekoihin. (Melkas-Löytty 2018b, 21.)

Novellin Albin ei palaa vankileiriltä vaan Venäjältä, mutta samalla hän palaa kuolleista. ${ }^{11}$ Hän on laihtunut teräväpiirteiseksi ja parta peittää hänen persoonalliset kasvonpiirteensä. Hän on palannut antautuakseen ja kärsiäkseen tuomionsa. Mari kuitenkin kokee esikoisensa palanneen kuolleista äitinsä luokse. Hän ei halua jakaa poikaansa muiden kanssa, ei perheensä eikä maallisen tuomioistuimen. Siksi hän menettää poikansa.

Äiti ja poika kohtaavat kodin ovella, mutta äiti kieltää poikansa pääsyn kodin suojaan, sillä nimenomaan suojaa se ei sotaan lähteneelle pojalle enää tarjoaisi. Siksi suoja järjestetäänkin syrjäiseen varastorakennukseen. Sinne Mari yrittää rakentaa kodin tuntua pojalleen erilaisilla tarvikkeilla ja huolenpidollaan. Mutta tämä ei-koti ja koko novellin kuvaama tilanne on lähtökohtaisesti väliaikainen, liminaali, eikä pojan kotiinpaluu koskaan toteudu.

Elisabet Ahon Sisar-romaanissa (2011) kuvataan kotiinpaluu, jossa palaajaksi oletettu on jo kuollut. Teoksen kokonaisuudessa vankileiriltä palaaminen on vain pieni kohtaus, jossa oikeastaan kukaan ei palaa, eikä kukaan ole vastassa. Siinä kuvataan diakonissalaitoksen portilla hortoilevaa ryysyistä olentoa, joka

11 Samankaltainen kuolleista palaaminen tapahtuu Hella Wuolijoen teoksessa Työmiehen perhe, jossa useita vuosia kadoksissa ollut ja kuolleeksi ja sorakuoppaan haudatuksi luultu vaimo ja äiti palaa kotiin. Hänet tulkitaan ensin nimenomaan haamuksi, kummitukseksi tai vainajaksi: "Taivas varjelkoon! Ihanko se on Riikka-vainaja?" Sekä vangituksi joutunut Riikka että sodasta hengissä selvinneet pojat ja puoliso ovat luulleet toistensa olleen kuolleita. Kirjoitetut kirjeet ja tieto hengissä selviämisestä eivät olleet tavoittaneet vastaanottajia. (Wuolijoki 1970, 127.) Wuolijoen teos on kirjoitettu alun perin kuunnelmaksi. Se perustuukin nimenomaan nokkelaan dialogiin. Siksi Riikan ja hänen puolisonsa jälleennäkeminen muistuttaa enemmän farssia kuin toisilleen rakkaitten ihmisten kohtaamista. Samalla se osoittaa, miten jälleennäkemiset eivät välttämättä ja aina ole yleviä, vaan niissä on myös groteski puolensa. 
oli niin laiha, etteivät he olleet koskaan nähneet hänenlaistaan edes kirjojen kuvissa, joissa onnettomat ihmiset kärvistelivät helvetin tulenlieskojen saartamina, posket kuopalla, nälkiintyneinä ja kauhujen vallassa. Nainen nojasi portinpieleen silkasta heikotuksesta, vaatteet resuisina riepuina, hiukset ohuina paakkuina ja jalat paljaina, verinaarmuilla hiekan ja kuran peitossa. Hän puristi kainalossaan epämääräistä kangasnyyttiä ja piti syvälle painunutta suutaan tiukasti kiinni, niin ettei huulista näkynyt viivaakaan ja saattoi vain aavistaa, että suusta puuttui hampaita. (Aho 2011, 100.)

Vankileirit - myöhemmin yksi diakonissoista lähtee työskentelemään Tammisaaren leirissä - ovat romaanin tulkinnan mukaan helvettiäkin pahempi kohtalo. Suomenlinnan vankileiristä hengissä selvinnyt nainen nojaa portinpieleen. Hän kantaa mukanaan jotain, joka on jäänyt jäljelle toisesta, joka ei selvinnyt. Naisen kainalossa olevassa kangasnyytissä on kaikki se, mitä diakonissalaitoksella majailevan pikkupojan äidistä on jäljellä. Pojalle kerrotaan ensin, että hänen äitinsä on palannut. Poika juoksee portille, jossa hän näkeekin äitinsä sijaan vieraan naisen. Tämän pojalle antama nyytti on samalla varmistus hänen äitinsä kuolemasta. Merkittävä osa sisällissotaan lähteneistä tai joutuneista sekä vankileireille suljetuista ei koskaan palannut. ${ }^{12}$

Lyhyen kohtauksen keskellä, näkymättömissä, on pojan kuollut äiti. Porttiin nojaava nainen tuo viestin tuonpuoleisesta, mutta on itsekin käynyt lähellä kuolemaa ja kokenut monenlaiset kärsimykset ja kauhut. 2010-luvulle tultaessa vankileiriltä palanneiden kuvaukset muuttuvat yksityiskohtaisemmiksi ja tuovat esiin koko kärsivän ruumiin, ei vain lommoille laihtuneita poskia tai kärsimyksen jäykistämää katsetta.

\subsection{Tappava ruoka}

Reilu vuosikymmen sodan jälkeen, vuonna 1932 ilmestyi Toivo Pekkasen läpimurtoromaani Tehtaan varjossa, jonka riipaiseva aloitus kuvataan lapsen, isäänsä kotiin odottavan pojan näkökulmasta. Pekkasen romaania luettiin sen julkaisuaikana 1930-luvun poliittisesti jännittyneessä ilmapiirissä kuvauksena siitä, miten vihollisuudet ja vastakkainasettelut voidaan ylittää. Romaani keskittyi selviämiseen ja jälleenrakennukseen, eli sisällissota jäi vain elämää tuhonneeksi välikohtaukseksi, jonka jälkeen oli jatkettava arkista elämää. (Pynttäri 2018, 151-152.)

Romaanin alkaessa eletään nälän ja surun kesää vuonna 1918. Kaupungin työläisillä ei ole työtä eikä ruokaa. He kokoontuvat asemalle odottamaan, tuoko juna sillä kertaa heidän vankileirillä viruneen isänsä, puolisonsa tai poikansa takaisin kotiin:

12 Kaikkiaan punaisten puolella taistelleista menehtyi reilu 27 ooo henkilöä. Taisteluihin osallistui kaiken kaikkiaan vajaa 80 ooo henkilöä. Ks. Suomen sotasurmat 1914-1922. < http://vesta.narc.fi/cgibin/db2www/sotasurmaetusivu/stat2> Haettu 29.7.2018 ja Itsenäisyys1oo.fi-sivusto. http://itsenaisyys10o.fi/sisallissodassa-vastakkain-kaksi-kouluttamatonta-armeijaa/. 
Likaisina, laihoina, kainalossa pieni mytty matkatavaroita, saapuivat kapinoitsijat kotiin. Heidän omaisensa kiiruhtivat heitä vastaan, ja ilosta osattomiksi jääneet kuiskivat toisilleen, kuka kukin on ja miltä hän näyttää. (Pekkanen 1932, 7.)

Perheenjäsenet odottavat palaavia kiihkeästi ja vakavina. Asemalla norkoilee kuitenkin myös muita, joutilaita, joille vankileiriltä palaavat ovat jonkinlainen viihdenumero, jota katsellaan ja ihmetellään. Vankileiriltä palanneet tunnistaa vaatetuksesta ja ulkonäöstä. Heitä ollaan vastassa.

Eräänä iltana tulee tuosta kaksipuolisesta, valkoiseksi maalatusta ovesta ulos muiden mukana viidennelläkymmenellä oleva mies ja astuu horjuen alas aseman portaita. Laiha, nuori poika nousee äkkiä ylös nurmikolla loikoilevasta joukosta ja rientää juosten häntä vastaan. He ovat isä ja poika; pojan isä on nyt tullut. Kansa näkee, että he vaihtavat muutaman sanan keskenään, niin hiljaa, ettei kukaan niitä kuule, ja sitten ottaa poika isänsä kainalosta kirjavaan puseroon käärityn mytyn, ja toisiaan kädestä pidellen he alkavat nousta jyrkkää, kirkolle johtavaa mäkeä. (Pekkanen 1932, 8.)

Samuel tunnistaa välittömästi isänsä, vaikka tämä on laihtunut, rähjäinen ja muuttunut. Kohtaaminen on intiimi, vaikka tapahtuu keskellä julkista tilaa. Isä ja poika tuntevat toisensa ja tarttuvat toistensa käsiin. Käsi kädessä kulkeminen ei ole vain kiintymystä vaan kohtaajien välisen suhteen kehollinen ilmaus. Jyrkkä katu on liikaa isän heikentyneille voimille ja ylös noustuaan hänen pitää istahtaa lepäämään. Poika katselee isäänsä "salaa, äänettömänä, ja häntä värisyttää oudosti: isän tukka ja parta ovat käyneet kummallisen harmaiksi” (Pekkanen 1932, 8). He jatkavat hiljaa matkaansa, käsi kädessä kulkien, toinen toistaan tukien. Isä jaksaa kävellä kotiin saakka, vaikka hengittääkin raskaasti ja nojaa aina vähän väliä talojen seiniin.

Äiti on toiveikkaana ovella vastassa ja juoksee puolisoaan vastaan. Hän alkaa touhukkaasti laittaa syötävää, mutta joutuu lähettämään Samuelin hakemaan jotain suuhunpantavaa naapurista. Perheen ruokavarat ovat äärimmäisen niukat. Äiti ei voi lopettaa itkemistä, vaikka mies yrittää viimein hengissä kotiin päästyään ajatella positiivisesti: "ehkä tästä nyt taas vähän kerrassaan selvitään”. Neljän alaikäisen lapsen äiti tietää kuitenkin, että huolet eivät ole ohitse vaan ruokaa on hankittava jokaiselle päivälle. Äiti valmistaa Samuelin tuomista aineksista ruokaa; isä syö, mutta sen jälkeen alkaa hänen vatsaansa polttaa. Liian pitkään liian heikolla ruualla ollut elimistö ei kestä vahvaa ruokaa, eikä isä nouse vuoteeltaan enää koskaan. (Pekkanen 1932, 9.)

Tämä kotiinpaluu on Tehtaan varjossa -teoksen prologi, lyhyt kohtaus, josta romaani ja Samuelin elämä vasta alkavat. ${ }^{13}$ Prologin keskeinen teema, tavallisen arkisen ruuan

13 Romaanin edetessä Samuel unohtaa isänsä ja kasvaa arvostetuksi työmieheksi. Vasta aivan teoksen lopussa hän solmii uudelleen isäsuhteensa. Hän kokee itse olevansa silta tuonpuoleisen ja tämänpuoleisen välillä, isänsä elämän ja elämäntyön jatkajana ja edistäjänä. Hänen tehtävänsä on kasvaa suuremmaksi ja nähdä pidemmälle kuin isänsä. (Pekkanen 1932; Pynttäri 2018, 153-154.) 
vaarallisuus, nousee esiin muissakin kotiinpaluun kuvauksissa sekä sitä koskevassa muistitiedossa. Esimerkkinä voisi mainita vaikkapa Irene Rajalan muistiinmerkitsemän Hildan kertomuksen, jossa kuvataan lapsen näkökulmasta yksityiskohtaisesti äidin vangitsemista, vankilassaoloaikaa ja kotiinpaluuta. Ruualla, sen puutteella, ruuan viemisellä vangituille, hyvien ihmisten lapsille antamalla ruualla ja liian vahvan ruuan tai liian suurien annosten vaarallisuudella on merkittävä rooli kerronnassa. (Suomalaisen Kirjallisuuden Seura.)

Niin muistitiedossa kuin kaunokirjallisuudessa on kertomuksia toisista, jotka maitoa tai lihaa syötyään kuolevat. Lisäksi on varoittavia kuvauksia kotiin palaavista, jotka pitkään vaikeita oloja kestäneinä eivät enää kestäkään kodin arkea ja arkista ruokaa. ${ }^{14}$ Kuin vastauksena Samuel Oinon isän kuolemaan vuosikymmeniä myöhemmin Hovimäki. Päin nousevan Suomen rantaa -teoksessa kotiin palaavalle, nälkiintyneelle Toivolle kieltäydytään antamasta leipää, sillä monen vangin tiedetään kuolleen suolisolmuun saatuaan liian vahvaa ruokaa. Toivo kuljetetaan kotiin ja uskotaan elämän pääsevän voitolle. Marttapuoliso keittää luurangonlaihalle puolisolleen lautasellisen velliä useita kertoja päivässä. Eräänä aamuna Toivo herää ja kokee olonsa hyväksi. Hän lähtee liikkeelle ja näkee tynnyrillisen suolasillejä, joita ei kykene vastustamaan. Yhtä silliä seuraa aina toinen. Lopulta hänet löydettiin kuolleena. (Mesterton ym. 2003, 482-484.) Puolison huolenpito ja hoiva eivät riitä pitämään hengissä ihmistä, joka on ollut liian kauan ilman kunnon ruokaa. Kun nälkiintynyt ruumis lopulta saa ravintoa, se ei kykene lopettamaan ahmimista.

\subsection{Kotiin palaava työtätekevä kansa}

Mihail Bahtinin $(1979,257)$ mukaan kohtaamisen kronotoopit ovat usein sekä teoksen juonen että sen henkilöhahmojen kannalta keskeisiä solmukohtia. Monissa tarkastelemissani romaaneissa kotiinpaluu sijoittuukin teoksen alkuun tai loppuun. Kohtaamiset joko aloittavat teoksen, kuten Toivo Pekkasen ja Eeva Joenpellon romaaneissa, tai päättävät sen, kuten Heidi Köngäksen romaanissa. Ehkä suomalaisen romaanikirjallisuuden tunnetuin vankileiriltä paluu tapahtuu Väinö Linnan Täällä Pohjantähden alla -romaanisarjan, vuonna 1960 ilmestyneen toisen osan lopussa.

Kuten Melkas ja Löytty $(2018 \mathrm{a}, 11-12)$ toteavat, "kaunokirjallisuudella on ollut erityinen rooli ja kyky käsitellä kansallista murhenäytelmää". Linnan trilogian toisen osan nähdään usein olevan juuri se romaani, joka aloitti kansallisten haavojen parantamisen ja käynnisti myös hävinneitten kertomuksia kuuntelevan historiantutkimuksen yli

14 Myös Heidi Köngäksen Sandra-romaanissa (2017) kotiin palaavaa isää ja puolisoa pitää pitkään varjella tavalliselta ruualta. Hänenkään nälkiintynyt elimistönsä ei kestä ruokaa, joten Sandra keittää löysää kauravelliä ja syöttää säännöllisin väliajoin sitä sekä sokeri-suolavettä miehelleen lusikalla. Juhani Syrjän omasta isästään kirjoittamassa monologiromaanissa Juho 18 (1998) pohditaan myös ruokaa. Juho kuvaa siinä saapumistaan uupuneena veljensä kotiin: "Perillä minua sukulaiseni säälittelivät. Ruokaa tarjottiin ja siitä varoitettiin. Join maitoa ja vähin kermaakin ja raakana kaksi kälyni kauppatavaraksi säästämää kananmunaa." (Syrjä 1998, 81-82.) Tiiviissä kerronnassa pannaan paljon painoa Juhon nuoruudelle, vahvalle ruumiille ja sille, miten tämän vatsa kestää ruokaa pitkän nälkiintymisen jälkeenkin. 
neljäkymmentä vuotta sodan jälkeen. Vasta silloin tosiasiassa ryhdyttiin julkisuudessa tarkastelemaan sisällissodan seurauksia ja laittomuuksia, kuten mielivaltaisia tuomioita ja teloituksia, vankileirejä ja eri kansanosien, luokkien ja yksilöiden välillä vallitsevaa vihaa. Vasta silloin alettiin myös kerätä katoamassa olevia muistoja ja kokijoiden kertomuksia. ${ }^{15}$

Linnan teossarja osoitti niitä monenlaisia syitä, jotka saivat tilattomat, maatyöläiset ja torpparit nousemaan kapinaan. He eivät olleet vain rosvoileva roskajoukko tai kommunistisen ideologian aivopesemä kiihkoileva ryhmä, minkälaisina siihenastinen vapaussotakirjallisuus oli punaiset nähnyt. Linna antoi äänen, nimen ja kasvot hävinneelle puolelle. Pohjantähti-trilogia teki heistä inhimillisiä, mikä mahdollisesti auttoi pääsemään vastakkainasettelujen ja yksipuolisten viholliskuvien yli. (Melkas-Löytty 2018a, 12; 2018b, 20; Varpio 2006, 471, 492.)

Pohjantähden Akselikaan ei edustanut vankileiriltä kotiin palatessaan vain itseään. Hän kävelee kotiin tilanteessa, jossa moni oli kuollut leirillä nälkään ja makasi haudattuna matalaan nälkämonttuun tai sorakuoppaan. Ne, jotka olivat Akselin tavoin säilyneet hengissä ja palasivat Hennalasta, Riihimäeltä, Tammisaaresta ja Tampereelta, olivat nälkiintyneitä ja laihtuneita. Kaikki eivät olleet päässeet pois, vaan heitä odoteltiin edelleen tai he eivät palaisi koskaan. Ja, kuten Ulla-Maija Peltonen $(1996,17)$ on tutkimuksissaan todennut, ne jotka menettivät läheisiään sisällissodassa tai vankileireillä, eivät sodan päättyessä ainakaan julkisesti uskaltaneet itkeä ja surra menetystään.

Mutta Linna näkee leireiltä palaavissa myös jotain positiivista: Kapinaan lähteneet olivat kokeneet monenlaista. He olivat nähneet maailmaa ja ajelleet junalla. He puhuivat tuttavallisesti ennen vieraista ja kaukaisista paikkakunnista ja niissä tapahtuneista taisteluista. He kertoivat leireillä kokemastaan elämästä tarinoita ja sattumuksia. Heitä kuunneltiin:

Heillä oli jotakin mitä ei vain kaikilla olekaan. Heillä oli Kohtalo. Kohtalo on jotakin suurempaa kuin tavallinen elämä. Se oli pannut syrjäkylän torpanpojan tai päiväläisen vastatusten suurten asioiden kanssa. He olivat kasvaneet, ja heidän maailmansa oli laajentunut. (Linna 1989 [1960], 255.)

Akseli Koskelan kävely kotiin kuvataan hitaasti ja kiirehtimättä. Sitä kehystetään marraskuisen, tihkusateisen illan kuvauksella. Kylä on autio ja hiljainen, tie hukkuu mustaan pimeyteen. Tien kronotooppi kuljettaa tuntemattomasta tulevaa kohti tunnettua, kotia, joka ensin tuntuukin oudolta:

Asemalta päin, tien mustasta pimeydestä, alkoi kuulua hiljaista jalkojen rasahtelua. Se koveni lähestyessään valonkajastusta, jonka piiriin pian ilmestyi miehen hahmo. Hahmon piirteet selkenivät sitä mukaa kuin se lähestyi osuuskaupan

15 Pohjantähden vaikutuksesta vuoden 1918 tulkintoihin ja arkistojen keruisiin ks. Ulla-Maija Peltonen 1996, 15-16, 98-102; Pohjantähden vastaanotosta sekä vaikutuksesta historiantutkimuksen käsityksiin ks. esim. Varpio 2006, 484-515; Jyrki Nummi 1993: Jalon kansan parhaat voimat. Kansalliset kuvat ja Väinö Linnan romaanit Tuntematon Sotilas ja Täällä Pohjantähden alla. WSOY, Helsinki; Vesa Vares 2018: Kun ikoni painaa liikaa. Kanava 2/2018. 
valoa. Miehen päässä oli hattu, jonka lierit olivat paljon kärsineet ja joka oli asetettu hiukan vinoon tuulta vasten. Pää oli myös kallellaan, mutta se pysyi liikkumatta samassa asennossa. Ulkonevat leukaperät olivat jäykistyneet kylmän vuoksi koholleen. Suupielistä lähti kuoppainen juonne korvaa kohti, ja selvästi näkyvät poskiluut olivat koholla. Syvällä olevat silmät katsoivat rävähtämättä maantietä. [...] Askel oli väsynyt, mutta vähän päästä siinä tuntui ahneempi ote - niin kuin tahto olisi välillä vaatinut ruumiilta enemmän kuin se katsoi sopivaksi, sillä hetken kuluttua askel hidastui kiivastuakseen uudelleen. (Linna 1989 [1960], 257.)

Kuvaus voisi olla valoilla ja varjoilla kuvatusta ranskalaisesta elokuvasta. Kävelijä voisi olla kuka tahansa pitkän poissaolon jälkeen kotiin palaava mies, mutta samoin kuin muissa sisällissotakuvauksissa, Akselikin kuvataan laihtuneena. Hänen poskiluunsa ovat koholla ja näkyvät selvästi. Silmät ovat syvällä kuopissaan. Mutta erojakin on. Vaikka Akseli on väsynyt, hän ei ole heikko samalla tavalla kuin vaikkapa Eeva Joenpellon Vieno, joka kaatui ojaan, eikä jaksanut nousta, tai Tehtaan varjossa -romaanin Samuel Oinon isä, joka tarvitsi kävelyssään tukea pojaltaan. Vuosikymmenen Linnaa ennen kirjoittanut Hella Wuolijoki $(1970,117)$ taas korostaa, miten "monikin voimakas mies jäi sille vapauden tielle, kun taas heiveröiset kestivät". Linna kuvaa Akselin tahdon niin vahvaksi, että mieli voittaa väsyneen ruumiin.

Pitkän poissaolon jälkeen kotiin johtava tie ja kotipiha ovat Akselilta osin unohtuneet. Välillä hänen pitää hapuilla löytääkseen oikean tien. Lopulta hän saapuu perille ja muistaa kotinsa: "Rappuja tunnustellen ja ovenpieliä sivellen hän asteli eteisiin. Käsi teki hapuilevan liikkeen ja löysi puisen vedikkeen. Sitten hän näki Elinan ja pojat, jotka olivat jäykistyneet niihin asentoihin mihin olivat jääneet kuullessaan ensimmäiset tunnustelevat askelet portaissa." Torpparin perheeseen tulee harvoin vieraita iltapimeällä, joten Akselin vaimo Elina ja perheen kolme poikaa odottavat tulijaa hämmentyneinä. (Linna 1989 [1960], 257.)

Mies tervehtii perhettään, vaimo astuu häntä vastaan pyyhittyään kätensä: "Kasvoilla oli monien vaihtelevien ilmeiden liike. Hymy ja itku eivät oikein antaneet toisilleen tilaa. Povi kohoili voimakkaasti. Hän tarttui käteen ja lehahti punaiseksi koko kasvoiltaan. Niin kuin joskus ensimmäisinä iltoina kun kohtauksen kiihkeys vielä ujostutti." Linna kuvaa aviopuolisoiden, toisilleen rakkaiden ihmisten kohtaamista kehon vahvoilla reagoinneilla. Sosiaaliset säännöt ja tarve peittää todelliset tunteet koskevat niin Akselia kuin Elinaakin, mutta Elina ei onnistu salaamaan voimakkaita tunteitaan. Tosin ensin he kättelevät toisiaan muodollisesti. Pitkään jatkuneen kättelyn jälkeen he syleilevät toisiaan, ja viimein kohtaukseen astuvat mukaan poissalon aiheuttamat muutokset: tutun puolison "silmistä katsoi joku kaukainen tuntematon ihminen". Kärsimykset, kuolemantuomio ja nälkä olivat jättäneet jälkensä Akseliinkin. (Linna 1989 [1960], 259.)

Akseli ei siis ole nälästä ja sairaudesta heikkona, kuten moni muu, mutta hänen kasvonsa muistuttavat toisten vankileiriltä palanneiden kasvoja: 
Miehen kasvot olivat jäykät, niiden laihtunut ja luiseva tummuus väreili yhteen ainoaan ilmeeseen jäykistynyttä ja paatunutta kärsimystä. Mutta pahinta oli katsoa hänen kuoppiin painuneita silmiään. Niissä oli tyhjä ja sammunut ilme, joka kuvasti vain jotakin raskasta ja elotonta. Kun hän koetti hymyillä pojalle, ilmestyi niihin väkisin tehtyä iloa, mutta suun hymy oli jäykkä ja vääristynyt. (Linna 1989 [1960], 259.)

Väinö Linna ei juurikaan kirjoita Akselin heikkoudesta tai laihuudesta, ainoastaan mielen raskaudesta, katseen tyhjyydestä, ilottomuudesta ja yleisestä poissaolosta. Menneisyydestä ei Koskelassa puhuta. Vaikka Akseli on kiinnostunut torpasta ja sen tulevaisuudesta, hän ei heti puutu työntekoon, vaan itselleen epäluonteenomaiseen tapaan kiertelee ja katselee. Lopulta hänkin reipastuu ja ryhtyy kasvattamaan lapsiaan näiden hälistessä ruokapöydässä:

- Pojaat. Mitäs on sanottu ruokapöydässä meluamisesta? Pojat lopettivat riitansa totisina. Elina auttoi Voittoa lusikoimisessa, ja hänen kasvoillaan oli iloinen ja keventynyt ilme. Pöydässä kuului vain lusikoiden kilinä. Muuten vallitsi hiljaisuus. Oikea evankelis-luterilainen hiljaisuus. Isä oli tullut kotiin. (Linna 1989 [1960], 262.)

Akselin kotiinpaluusta tulee totta vasta, kun hän ottaa itselleen takaisin isän ja isännän kielen ja asenteen. Ja silloin perhe tuntee hänet.

Hella Wuolijoen Työmiehen perheessä ${ }^{16}$ tien kronotooppi on paikka, jossa yhden kulkijan, kotiin palaavan Jaakko Rantasen, keralla kulkee Akselin tapaan koko Suomen katajainen, työtätekevä kansa:

[Rantanen kulki] maantietä katajaiseen keppiin nojaten kalpeana ja väsyneenä ryysyisissä vaatteissa. Keskikesän aurinko helotti ja apila tuoksui. Mies astuskeli varovaisesti, istuutui kivelle maantien viereen levähtämään ja katseli tuimana ja välinpitämättömänä kesän kauneutta. Huomasi ja kulki eteenpäin, katajainen vapisevassa kädessä. Paljon kulki Suomenmaalla sinä kesänä tällaisia repaleisia miehiä, joiden vaatteissa oli omituinen köyhyyden, lian ja lysolin haju. [...] Näin he kulkivat ehdonalaisina, vankeina, nälän uuvuttamina. Mitä voimakkaampi mies, sitä heikommin hän kulki, silmät tuimina, toivottomina, tietämättömänä kotioloistaan ja tulevaisuudestaan. [...] Siinä kulki Suomen työmies harmaana, arkipäiväisenä, lopen uupuneena, eikä kukaan muistanut, että hänkin oli osoittanut sankaruutta, taistellut ja kaatunut ja tullut voitetuksi. (Wuolijoki 1970, 108.)

Linnan tapaan Wuolijoki muistuttaa siitä, että hävinneet olivat myös kokeneet jotain erityistä: he olivat osoittaneet sankaruutta ja taistelleet. Tässä kuvauksessa tien kronotooppi

16 Wuolijoki kirjoitti teoksensa kuunnelmaksi heti talvisodan jälkeen 1940, mutta se julkaistiin kirjana vasta 1970. Wuolijoki lienee ensimmäisiä, jotka tarkastelivat sisällissotaa punaisia ymmärtävästä näkökulmasta. Ennen talvisotaa se ei ollut mahdollista. (Ks. Heimo 2010, 127; Niemi 1988.) 
kuvastaa välitilaa, jossa kotiinpalaajat elivät. ${ }^{17} \mathrm{He}$ olivat eläneet poikkeuksellista aikaa, mutta heidän tulevaisuutensa oli edelleen epävarma. He eivät tienneet, minkälainen koti heitä odotti, mutta se oli varmaa, että he eivät palanneet samaan kotiin ja kotimaahan, josta he olivat sotaan lähteneet.

\subsection{Kotiin palaakin lapsi}

Eeva Joenpellon Vetää kaikista ovista -romaanin alussa Tilta Gröönroosin poika Vieno palaa kotiin. Tilta kertoo kohtaamisesta vahvalla murteellaan. Hän kuvaa, miten oli lähtenyt käymään kylässä myydäkseen viimeisen arvoesineensä, hopealusikan, jotta saisi tyttärensä haudatuksi. Kotimatkalla hän näki poikansa: "Nii kum mää tulin kotjak käsi nii ihan siin poluv viäres makas Viano kuraprotis. Neljä tuntii se oli kräviny tota matkaa asemalt tännek kättä.” Voimat olivat ehtyneet ennen kotia, mutta Tilta auttoi hänet perille. Vierailulle tulleet Hännisen sisarukset kyselivät, oliko Vieno se heidän ulkona näkemänsä vanha mies. Tilta vastaa:

Kakskymmentkaksvuatias vanha miäs. Ja jos emmää ny enää osakkan parkuu nii kyl hän osaa senki eres. Sanoo sanan tai kaks, sit jo rupee poramaa. Mää lämmyti saunan, pesi ja krassasi ku piänel lapsen. Se oli mun omaa luutan ja nahkatan kum mää siin kylveti ja sit mää taluti sen sänkyy. Tual se ny istuu, trappusil. (Joenpelto 1972, 34.)

Vankileiriltä palanneet olivat nälän ja sairauksien heikentämiä, niin että pienimmätkin ponnistukset olivat heille ylivoimaisia. Myös Vienon voimat olivat ehtyneet kotimatkalla. Henkiset voimatkin olivat vähissä, minkä vuoksi hän - tuon ajan miehille epätyypilliseen tapaan - itki. Vaikka Vienon olisi nuorena, 22-vuotiaana miehenä kuulunut olla vahva, oli hän nyt heikko kuin pieni lapsi. Ja lapsena Tilta häntä kohtelikin. Hän teki normaalit lapsen iltarutiineihin kuuluvat toimet: pesi, kylvetti ja vei sänkyyn nukkumaan. Lapsi on äidin omaa lihaa ja verta vielä aikuisenakin.

Heidi Köngäksen (2017) romaanissa Sandra odotetaan palaavaksi isää. Romaanin kehystarinana on nykypäivän moderni näyttelijä, joka perehtyy isoäitinsä Sandran tarinaan ja samalla oman sukunsa ja perintötalonsa menneisyyteen. Sandran näkökulmasta kerrotun romaanin lopussa on sisällissota seurauksineen. Hänen puolisonsa Janne osallistuu kapinaan ja joutuu vangituksi. Sandra puolestaan saa yksin huolehtia kaikesta: synnyttää vauvan, joka ei jää eloon, hoitaa torppaa, eläimiä ja taksvärkkiä sekä pitää huolta lapsistaan.

Se oli Sandralle ylivoimaista ja siksi hän odotti palavasti puolisoaan kotiin. Hän lähetti poikansa joka päivä junalle vastaan, siltä varalta, että perheen isä tulisi sinä päivänä kotiin.

17 Tien kronotooppi näkyy myös Juhani Syrjän Juho 18 -romaanissa (1998). Juho tekee siinä pitkää kotiinpaluutaan kävellen vankileiriltä lapsuudenkotiinsa vieraillen ensin veljensä perheen luona, jossa opettelee syömistä ja kunnostaa vaatteitaan. Koska pienoisromaani on kirjoitettu Juhon itsensä näkökulmasta, teos poikkeaa muista käsitellyistä. 
Hän oli mielessään kuvitellut kotiinpaluun monta kertaa. Miten juna saapuisi asemalle, miten "mies astuisi junasta, näkisi omat poikansa, jo kaukaa tunnistaisi oman hevosensa." Sandra oli laittanut joka päivä pojille mukaan eväät myös isälle, että tämä saisi jotain suuhunsa pitkän matkan jälkeen. Kuvitelma osoittautui pelkäksi kuvitelmaksi. Janne-puoliso tuli joulukuussa 1918 kotiin, mutta eri tavoin:

Pojat eivät olleet tunteneet häntä asemalla. He olivat jo kääntyneet kohti hevosta palatakseen taas kerran ilman isää kotiin, kun eräs vilppulalainen oli huutanut heidät takaisin. Janne oli tuupertunut kontalleen asemalaiturille eikä ollut päässyt omin voimin ylös. Pojat saivat hänet juuri ja juuri talutettua ja lähes raahattua hevosen luo, isä ei meinannut jaksaa kävellä. Asemamies oli lopulta ehtinyt avuksi ja hänet saatiin hilattua rekeen. (Köngäs 2017, 193-194.)

Kohtaus on Tehtaan varjossa -romaanin Samuel Oinon ja hänen isänsä kohtaamisen peilikuva: pojat eivät tunnistaneet isäänsä. He olivat lähteneet hakemaan isäänsä, mutta olivat kohdanneet jotain muuta, jotain hävettävää. Kun pojat tuovat isänsä kotiin, Sandra kiiruhtaa puolisoaan vastaan. Häntä odottaa järkyttävä näky: ”vain kireä nahka oli jäänyt kasvojen päälle, joista kaikki rasva sulanut pois ja kasvoluut näkyivät kuin vanhoilla miehillä juuri ennen poislähtöä. Minun iso vahva mieheni oli sulanut luukasaksi. Pelottavalta hän näytti." Jannen kasvot olivat laihtuneet, kuten muillakin, aiemmissa romaaneissa kuvatuilla kotiinpalaajilla, mutta kuvaus hänestä on aiempia yksityiskohtaisempi ja suorempi. Jannen kasvot eivät ole pelkästään vanhan miehen kasvot, vaan ne ovat pelottavat ja kertovat kuolemasta. Sandra ja pojat auttavat Jannen sisään. Tämä käy ovensuunpenkille makaamaan, ja Sandra riisuu hänen kenkänsä:

ja kun näin, missä kunnossa paljaat jalat olivat, työnsin tallukat takaisin jalkaan ja komensin lapset pikkukamariin. Maija [Jannen äiti] tuli ja nostimme yhteisvoimin Jannen ylös ja kahta puolta tukien saimme hänet vesikelkalla kiskottua saunalle. Emme vaihtaneet montakaan sanaa, vaan toimimme. Mies riisuttiin saunan eteiseen, minulla oli lämmintä vettä padassa, olin senkin joka ilta valmiiksi lämmittänyt, vaikken ollut yhtään käsittänyt, millaisessa kunnossa hän voisi olla. (Köngäs 2017, 194.)

Maija kirosi nähdessään poikansa tilan. Yhdessä naiset pesivät Jannen, "porstasivat" häntä "kuin lasta". Kaikki hänen päällään olleet vaatteet heitettiin ulos poltettavaksi. Pesun jälkeen Janne nukahti heti sänkyynsä. Kuten Vienoa, myös Jannea kohdellaan kuin lasta. Hänen äitinsä ja vaimonsa pesevät hänet ja laittavat sänkyyn nukkumaan.

Niin Pohjantähden Akselin kuin myös Jannen kohdalla kotiinpaluu on pitkään kestävä tapahtuma. Vaikka mies on fyysisesti palannut, hän ei ole henkisesti läsnä, eikä hänen henkiinjäämisensä ole varmaa. Janne on palannut joulukuussa, mutta vielä tammikuussa Sandra pohtii tuskissaan: 
Janne menee, Janne menee, ei voi mitään, me emme pysty pitämään häntä, kaikki menee, päästä huippaa, veri ei kierrä, en ole nukkunut yhtään yötä sen jälkeen kun hän palasi kotiin. Mutta kuka sieltä palasi? Jäikö hänen todellinen itsensä jonnekin matkan varrelle, unohtui sinne ja paleltui pois. Minä en tunne tätä miestä, joka väittää olevansa minun mieheni. Hänestä ei ole jäljellä enää mitään muuta kuin nokka joka roikkuu tyhjän päällä ja veriuloste jota juoksetan laskiämpärillä huussiin. (Köngäs 2017, 196.)

Kuolema ei ole jäänyt taakse puolison palattua, sillä kuumeinen Janne anelee vaimoltaan: "Anna mun mennä". Mutta Sandra ei anna periksi. Vasta helmikuussa miehen kuume hellittää, ja hän saa ruokahalunsa ja hiljalleen myös elämänvoimansa takaisin. Hän jaksaa katsoa puolisoaan ja puristaa tämän kädestä:

Kiitokseksi kai, sillä hän katsoi taas kuin ennen, kauan kauan sitten. Autoin hänet takaisin pitkälleen ja alkoi tuntua siltä, että käyn itsekin hänen viereensä makuulle, menin saman peiton alle ja kuulin, kuinka hän nukahti heti. Hengitys kävi jo paremmin. Käännyin omalle puolelleni, makasimme selkä selkää vasten ja ajattelin lämmittäväni häntä, mutta samalla tunsin, että hän lämmittikin minua. Tajusin hänen palanneen. (Köngäs 2017, 206.)

Kun Akseli Koskelan paluu tapahtuu muutamassa päivässä ja hänen kotiintulonsa varmistaa ärähtäminen lapsille perheen yhteisessä ruokapöydässä, 2000-luvun kotiinpaluun kuvauksessa on realistisempi ote, paluu ja toipuminen ovat hitaita. Kotiinpaluun hetki on miehen ja vaimon kahdenkeskinen, intiimi aikatila, kädenpuristus ja nukahtaminen vieri viereen.

\section{Kotiinpaluun kronotoopit}

Olen edellä kuvannut, miten suomalaisessa kaunokirjallisuudessa on eri vuosikymmeninä kuvattu vuoden 1918 sodasta ja sen jälkeisiltä vankileireiltä kotiin palaavia miehiä ja naisia. Kuvauksen näkökulma on useimmiten kaikkitietävän kertojan mutta usein myös kotona odottavan vaimon ja äidin. Vain yhdessä, Juhani Syrjän dokumentaarisessa, omasta isästään kirjoittamassa romaanissa, on näkökulma kotiin palaavan, ja Toivo Pekkasen osin omaelämäkerrallisessa romaanissa näkökulma on hänen omansa, pienen pojan.

Kohtaamisissa vaihtelevat toivon ja epätoivon tunteet. Kotiin odotetaan vastuuta kantavaa ja velvollisuuksistaan huolehtivaa isää ja puolisoa, mutta kotiin palaakin nälästä heikko ja sairas mies, jonka toipuminen kestää pitkään tai joka ei toivu ollenkaan. Kohtaamisen kronotoopissa kohtaajien roolit saattavat kääntyä päälaelleen: pojasta tulee isänsä tukija ja taluttaja, vaimosta miehensä hoivaaja, pesijä ja ruokkija. Kehon kronotooppi onkin kotiinpaluun kuvauksissa hauras, hädin tuskin läsnä oleva, kuolemaan katsova. Se kaipaa huolenpitoa, hoivaa, ruokkimista ja pesua. Tuoreemmassa sisällissotakirjallisuudessa ruumiin eritteitä, heikkoutta, fyysisiä vammoja, kipuja ja likaa kuvataan 
yksityiskohtaisesti, kun taas vanhemmassa kirjallisuudessa tyydytään kuvaamaan nälän aiheuttamaa kasvonpiirteiden terävöitymistä tai kärsimysten kovettamaa katsetta.

Kotiinpaluun kuvauksissa tuonpuoleisuus on vahvasti läsnä: Kotiinpalaajaa luullaan kummitukseksi, koska hänen oletetaan tai tiedetään kuolleen. Kotiin palaava voi kuolla pian palattuaan tai elää pitkään elämän ja kuoleman rajamailla. Myös kauhua ja kärsimystä sisältäviksi kuvatut vankileirikokemukset, siellä vallinneet kuolemanpelot ja koetut julistukset kuolemantuomioista ovat leimanneet kotiinpalaajat kuoleman merkillä. Heidän kuihtunut ruumiinsa muistuttaa kuollutta tai kuolevaa. Vaikka ruumis on elossa ja kotona, sen kantaja on vielä osin tuonpuoleisessa tai välitilassa. Ehkä juuri siksi kestää aikansa, ennen kuin he kotiutuvat, palaavat takaisin tämänpuoleiseen elämään, kotoutuvat omaan kehoonsa ja kodin arkeen.

Mihail Bahtinin tien kronotoopissa tie tai sillä kuljettu matka voivat representoida elämänkulkua. Käsittelemissäni kotiinpaluissa tie, jota pitkin kotiin palaava kävelee, symboloi ennemmin rajatilaa, liminaalia, jossa kuljetaan kohti tunnettua, kotia, joka kuitenkaan ei odota samanlaisena kuin silloin kun sieltä on lähdetty. Kotiinpalaajan menneisyydessä, siellä mistä tie alkaa, on helvetinkaltainen kärsimyksen tila, jonka kulkija haluaa jättää taakseen.

Aika ja sen kokeminen sekä ajan suhteellisuus ovat näkymättömiä, mutta ne tulevat kaunokirjallisuudessa näkyviin kronotoopeissa. Keskeisenä taustalla olevana kronotooppina häälyy kotimaa, kansakunta ja erityisesti se, mitä muutoksia sota oli siihen tuonut. Vaikka kuvattu marraskuinen sää tai kesäinen luonto olivat samanlaiset kuin ennenkin, paljon, mahdollisesti kaikki, oli muuttunut. Väestöryhmien välinen luottamus oli tiessään, monet ystävät tai perheenjäsenet olivat kadonneet, kuolleet tai haavoittuneet. Oma kansalaisluottamus oli kadotettu. Palaajien kuvattiin kuitenkin katsovan luottavaisesti tulevaisuuteen. Jos he itse eivät siihen kyenneet, heidän puolisonsa, lapsensa tai äitinsä tekivät sen heidän puolestaan.

Vaikka kotiinpaluun kuvauksia voi tarkastella kohtaamisen, kehon, kodin ja kotimaan kronotooppisten yksiköiden avulla, näkemykseni mukaan niiden keskeinen aikatila on välitilan tai liminaalin kronotooppi. Bahtin itse (1979, 412-413) näkee kynnyksen kriisien ja elämän muutoskohtien kronotoopiksi. Hänen mukaansa se liittyy "elämän käännekohdan momenttiin, kriisiin tai muutoksen tekevään ratkaisuun (tai epäröintiin, pelkoon astua kynnyksen yli)”. Kotiin palaavat useimmiten kävelevät kotiinsa tietä pitkin, ja itse matkanteko on välitilassa kulkemista. Ne, jotka pääsevät kotiin asti, elävät useimmiten edelleen välitilassa, ennen kuin asettuvat omaan kehoonsa ja kotiinsa ja ryhtyvät elämään elämää eteenpäin. 


\section{Lähteet}

\section{Aineisto}

Aho, Elisabet 2011: Sisar. Otava, Helsinki.

Joenpelto, Eeva 1972: Vetää kaikista ovista. WSOY, Helsinki.

KöNGäs, HeIdi 2017: Sandra. Otava, Helsinki.

LinNa, VÄINÖ 1989 [1960]: Täällä Pohjantähden alla II. WSOY, Helsinki.

Mesterton, Anna-Lissa - Carl Mesterton - Kirsti Manninen - Jussi-Pekka Aukia 2003: Hovimäki. Päin nousevan Suomen rantaa. Gummerus, Jyväskylä.

PekKanen, Toivo 1932: Tehtaan varjossa. WSOY, Helsinki.

SCHILdT, Runar 1983 [1919]: Kotiinpaluu ja muita novelleja. Alkuteos Hemkomsten och andra noveller. Suomentanut Ilmari Ahma. Love Kirjat, Helsinki.

SYRJÄ, JuHANI 1998: Juho 18. Gummerus, Jyväskylä.

WUOLIJOKI, Hella 1970: Työmiehen perhe. Työmies Rantasen perheen kronikka vuosilta 1895-1945. Weilin \& Göös, Helsinki.

\section{Kirjallisuus}

ANDERSON, Benedict 1991: Imagined Communities: reflections on the origin and spread of nationalism. Verso, London.

Bahtin, Minail 1979: Kirjallisuuden ja estetiikan ongelmia. Suomentaneet Kerttu Kyhälä-Juntunen ja Veikko Airola. Kustannusliike Progress, Moskova.

1981: Forms of time and of the chronotope in the novel. Michael Holquist (toim.): The Dialogic Imagination: Four Essays by M.M. Bakhtin, 84-258. University of Texas Press, Austin.

Douglas, Mary 1991: The Idea of Home: A Kind of Space. Social Research 58:1, 287-308.

Fingerroos, Outi 2004: Haudatut muistot. Rituaalisen kuoleman merkitykset Kannaksen muistitiedossa. Suomalaisen Kirjallisuuden Seuran Toimituksia 985. Suomalaisen Kirjallisuuden Seura, Helsinki.

Heimo, Anne 2010: Kapina Sammatissa. Vuoden 1918 paikalliset tulkinnat osana historian yhteiskunnallisen rakentamisen prosessia. Suomalaisen Kirjallisuuden Seuran Toimituksia 1275. Suomalaisen Kirjallisuuden Seura, Helsinki.

Knott, Kim 2005: The Location of Religion. A Spatial Analysis. Equinox, London.

MelKas, KuKKu - Olli LöYtTy 2018a: Miten kirjallisuus kohtaa sodan? KuKKu MelKas ja Olli LöytTY (toim.): Toistemme viholliset. Kirjallisuus kohtaa sisällissodan, 9-12. Vastapaino, Tampere.

MelKas, KuKKu - Olli LÖYtTy 2018b: Sisällissotakirjallisuuden laskoksia. KuKKu MelKas ja Olli Löyтty (toim.): Toistemme viholliset. Kirjallisuus kohtaa sisällissodan, 13-33. Vastapaino, Tampere.

Peltonen, Ulla-Maija 1996: Punakapinan muistot: tutkimus työväen muistelukerronnan muotoutumisesta vuoden 1918 jälkeen. Suomalaisen Kirjallisuuden Seura, Helsinki.

Pynttäri, Veli-Matti 2018: Paljonpuhuvat prologit. KukKu Melkas ja Olli Löytty (toim.): Toistemme viholliset. Kirjallisuus kohtaa sisällissodan, 148-160. Vastapaino, Tampere.

SAARIKANGAS, KIRSI 1998: Tila, konteksti ja käyttäjä. Arkkitehtonisen tilan, vallan ja sukupuolen suhteista. Kirsi SAARIKANGas (toim.): Kuvasta tilaan. Taidehistoria tänään, 247-298. Vastapaino, Tampere.

Suomalaisen Kirjallisuuden Seura n.a. Irene Rajalan muistelmat 2917-1918. "Hilman kertomus." Suomalaisen Kirjallisuuden Seura. Arkisto.

Tuan YI-Fu 2001 (1977): Space and Place. The Perspective of Experience. University of Minnesota Press, Minneapolis.

Tweed, Thomas A. 2006: Crossing and Dwelling: A Theory of Religion. Harvard University Press, Cambridge, MA.

VARPIO, YRJÖ 2006: Väinö Linnan elämä. WSOY, Helsinki. 
VICE, Sue 1997: Introducing Bakhtin. Manchester University Press, Manchester \& New York.

Vilkкo, ANNi 1998: Kodiksi kutsuttu paikka. Tapausanalyysi naisen ja miehen omaelämäkerroista. Matti Hyvärinen, Eeva Peltonen ja Anni Vilkko (toim.): Liikkuvat erot. Sukupuoli elämäkertatutkimuksessa, 27-72. Vastapaino, Tampere.

\section{TIINA MAHLAMÄKI: Chronotopes of homecoming in Finnish literature on the Finnish Civil War}

The article examines six novels and one short story which describe the aftermath of the 1918 Finnish Civil War. It focuses on descriptions of the homecomings of husbands, wives and sons from the war and prison camps. The article explicates the ways the novels, which were written during various decades, chronicle these homecomings. Examining the point of views of those returning and those waiting as they encounter one another, the article discloses themes that are emphasised and themes that are repeated. The concept of chronotope by Mikhail Bakhtin (1979) is used an analytical tool. The article asks what types of chronotopes are applied in the construction of these encounters upon return. Four themes emerge in the descriptions: the dead returns home, lethal food, homecomers as working people and a child returns home. By examining these homecomings through Thomas A. Tweed's chronotopical units of body, home and homeland, the chronotope of liminality manifests itself as a more important unit.

Tiina Mahlamäki tituma@utu.fi Uskontotiede 20014 Turun yliopisto 